\title{
En 52 år gammel kvinne med feber og lungesvikt
}

\author{
Alvorlig lungeinfeksjon er den hyppigste årsaken til akutt oppstått \\ livstruende respirasjonssvikt. Ved manglende effekt av antibiotika- \\ behandling bør man tenke på muligheten av andre årsaker enn \\ infeksjon. Utredning bør være omfattende og skje raskt.
}

Se kommentar side 2372 og kunnskapsprøve på www.tidsskriftet.no/quiz

En 52 år gammel kvinne ble innlagt $i$ medisinsk avdeling etter at hun i to uker hadde vært febril, slapp, hatt sår hals og noe produktiv hoste. Hun hadde ingen kjente allergier og brukte ingen faste medikamenter. Fra tidligere var hun appendektomert, hadde fått påvist cervikal intraepitelial neoplasi, CIN III, med konisering og hadde også vært innlagt pga. urolithiasis. Hun hadde noen måneder tidligere fått påvist hepatitt $C$-antistoff. Hun var nylig testet negativ for hepatitt $B$, hepatitt A, hiv, Epstein-Barr-virus og cytomegalovirus (CMV). Hun hadde aldri fått blodprodukter.

Bakteriell eller viral infeksjon er vanlig årsak til langvarig feber, men både immunopatier og cancersykdom er aktuelle differensialdiagnoser.

Ved innkomst var hun våken og orientert, med temperatur $37,6^{\circ} \mathrm{C}$. Det var små, ømme hevelser medialt på legger og ankler som hadde oppstått de siste par dager. Hun var lett bankeøm over begge nyrelosjer. $\mathrm{O}_{2}$-metningen var $100 \%$ uten oksygentilførsel. Røntgen thorax viste diskrete, stripete fortetninger basalt på høyre side. Laboratorieprøvene ved innkomst viste: Senkningsreaksjon 101 $\mathrm{mm}, \mathrm{Hb} 10,7 \mathrm{~g} / 100 \mathrm{ml}$, leukocytter 21,8 · 10\% $/ \mathrm{l}$ hvorav nøytrofile granulocytter utgjorde $92 \%$, trombocytter $613 \cdot 10^{9} / \mathrm{l}, \mathrm{CRP} 137 \mathrm{mg} / \mathrm{l}$, kreatinin $109 \mu \mathrm{mol} / \mathrm{l}$, karbamid $37,5 \mathrm{mmol} / \mathrm{l}$, albumin $18 \mathrm{~g} / \mathrm{l}$, ASAT $85 \mathrm{U} / \mathrm{l}$, ALAT $79 \mathrm{U} / \mathrm{l}$, ALP 209 U/l, GT 297 U/l. Mononukleosetest ga negativt resultat. Dagen etter innkomst viste urinstiks: albumin 2+, $\mathrm{Hb} 3+$, leukocytter $1+$ og glukose 0 . Urinsedimentet viste like mengder plateepitel og leukocytter, ingen sylindre. Det ble tatt en rekke bakteriologiske prøver inklusive blodkulturer.

Feber, leukocytose med nøytrofili og forhøyet CRP-verdi er vanlige funn ved bakteriell infeksjon. Før igangsetting av antibiotikabehandling er det viktig å sikre seg adekvat materiale for bakteriologisk diagnostikk. Ved virale infeksjoner ser man vanligvis ikke så høy CRP-verdi og heller ikke så uttalt granulocytose. Lav albumin ble tilskrevet alvorlig infeksjon, men kan også ses ved en rekke andre alvorlige sykdommer. Lett forhøyet kreatininnivå ble forklart med dehydrering. Moderat forhøyede verdier av leverenzymer kunne tilskrives hepatitt C. Bakterielle infeksjoner er den hyppigste årsaken til pasientens sykdomsbilde, og andre diagnoser ble på dette tidspunktet ikke vurdert. På grunn av bankeømhet $\mathrm{i}$ begge nyrelosjer antok man at det forelå pyelonefritt, og det ble startet behandling med et bredspektret antibiotikum, cefotaksim. Ved mistanke om alvorlig urinveisinfeksjon er det viktig å avklare om det foreligger avløpshinder, og ultralyd abdomen ble derfor rekvirert. Det er ikke angitt i journalen om hun har dysuri, og urinsedimentundersøkelse og urinstiks viste ikke sikre holdepunkter for urinveisinfeksjon. Pneumoni ble utelukket på grunn av sparsomme lungefunn.

Ultralyd abdomen dagen etter innkomst avdekket bilateralt lett dilaterte nyrebekken, med noe mer markerte calyces på venstre side og bilateralt høyekkogent nyreparenkym. Etter fire dager ble det tatt prøve til nye blodkulturer på grunn av manglende klinisk respons på antibiotikabehandling. Cefotaksim ble seponert etter sju døgn. Etter ti døgn hadde hun fortsatt hoste, redusert allmenntilstand og temperatur opp mot $40^{\circ} \mathrm{C}$. Laboratoriesvar dag 10: CRP $99 \mathrm{mg} / \mathrm{l}$, leukocytter $26,9 \cdot 10^{9} / \mathrm{l}$ med $85 \%$ nøytrofile granulocytter, albumin $20 \mathrm{~g} / \mathrm{l}$, kreatinin $79 \mu \mathrm{mol} / \mathrm{l}, \mathrm{kar}-$ bamid 11,9 mmol/l, ALP $313 \mathrm{U} / \mathrm{log}$, GT 384 $U /$ l. Hun anga luftsmerter og fikk etter hvert diaré. Det ble påvist Clostridium difficile tok$\sin A$ i feces, og man startet behandling med metronidazol (Flagyl) per os. 11 døgn etter innkomst utviklet hun dyspné, takypné og fikk blodtilblandet ekspektorat.

Clostridium difficile-infeksjon kan forklare diaré, feber og høy CRP-verdi, men ikke de $ø$ kende luftveissymptomene. Endokarditt er en aktuell differensialdiagnose ved langvarig feber og organsvikt og må derfor utelukkes selv om det ikke var oppvekst i blodkultur. Det samme gjelder lungeemboli som kan gi alvorlig hypoksi og hemoptyser.
Røntgen thorax viste utbredte konfluerende fortetninger (fig 1). CT abdomen og CT thorax viste noe væske omkring høyre nyre, litt perikard- og pleuravæske og lett dilatert høyre colonhalvdel og transversum, ingen holdepunkter for lungeemboli. Ekkokardiografi viste velfungerende myokard og klaffeapparat uten mistanke om endokarditt. Hun ble overflyttet til intensivavdelingen. Etter noen timer måtte hun intuberes og tilkobles respirator på grunn av respirasjonssvikt.

Pasienten hadde nå utviklet alvorlig lungesykdom til tross for behandling med et bredspektret antibiotikum. Det ble derfor startet utredning med tanke på lungepatogene mikrober som ikke dekkes av cefotaksim.

Det ble utført bronkoskopi med biopsi fra midtlappsbronchus. Skyllevæske fra bronkien viste moderat vekst av hvite stafylokokker. Pneumocystis jerovecii og syrefaste staver ble ikke påvist i skyllevæsken. Det ble ikke påvist legionellaantigen i urin. Serologisk prøve var negativ for Mycoplasma, adenovirus, influensavirus, Chlamydia pneumoniae, CMV, hantavirus og Francisella tularensis. Ingen vekst i blodkulturer eller urin. Pasienten ble videre behandlet med krystallinsk penicillin, ciprofloksacin og metronidazol. På grunn av mulig immunsvikt med lav s-lgG, $5 \mathrm{~g} /$ l, fikk hun immunoglobulin intravenøst $i$ to døgn. Antibiotikabehandlingen ble supplert med erytromycin $500 \mathrm{mg} \times 2$.

Pasienten var kritisk syk til tross for langvarig bredspektret antibiotikabehandling. Diagnostisk var situasjonen uavklart, og man begynte derfor å lete etter ikke-infeksiøse årsaker, som immunopatier.

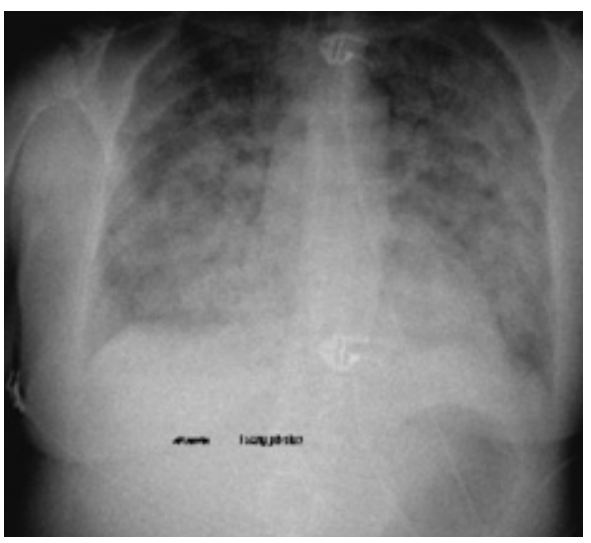

Figur 1 Utbredte konfluerende fortetninger på røntgen thorax 
Antistoffundersøkelser viste normale funn for ANA, anti-GBM, ANCA, anti-proteinase 3 og ant-myeloperoksidase. Serum-ACEnivået var normatl.Komplementkvantitering viste normal C3, 0,89 g/l, men lav C4, $<0,05 \mathrm{~g} / \mathrm{l}$.

Kreatininnivået steg til $129 \mu \mathrm{mol} / \mathrm{l}, \mathrm{karba}$ midnivået til 23,2 mmol/l. Urinstiks viste nå røde blodceller $3+$ og protein 3+. Urinsedimentundersøkelse viste mange kornede og hyaline sylindre samt ovale fettlegemer. Undersøkelse i polarisert lyst viste malteserkors forenlig med fettdråper i urin.

Kombinasjonen av nyre- og lungeaffeksjon kunne være forenlig med systemsykdom. Goodpastures syndrom, Wegeners granulomatose og SLE var lite sannsynlige pga. negative anti-GBM-, ANCA- og ANA-tester. Immunologisk sykdom som omfatter lunge og nyre kan ha et livstruende forløp. Rask diagnostisk avklaring er viktig fordi en slik alvorlig immunologisk lidelse krever intensiv immunsuppresjon. Urinsedimentundersøkelse ga i dette tilfellet viktig informasjon om mulig parenkymatøs nyrelidelse. Mange kornede og hyaline sylindre kombinert med påvisning av fett $\mathrm{i}$ urin var forenlig med nefrotisk proteinuri, som forekommer blant annet ved glomerulonefritt. Nyrebiopsi har vist seg å være et godt hjelpemiddel for diagnostisk avklaring. De viktigste sykdommer som kan gi akutt kombinert lunge og nyreaffeksjon er angitt $\mathrm{i}$ tabell 1 .

Det ble startet med SoluCortef $100 \mathrm{mg}$ tre ganger daglig. Dagen etter ble det utført nyrebiopsi. Det ble funnet forandringer forenlig med membranproliferativ glomerulonefritt. Dessuten ble det funnet trombeliknende materiale i glomeruluskapillarer (fig 2), små segmenter med granulocytter i glomeruli og iskemiske tubulusendringer.

Lungebiopsien viste intravaskulære kapillære platetromber med enkelte granulocytter og meget lettgradig, uspesifikk akutt betennelse med nedslag av makrofager. Senere utført immunfluorescens viste ingen sikre nedslag av immunglobuliner eller komplement. I alveolene fant man utbredt blødning (fig 3). Det ble ikke gjort sikkert funn av vaskulitt eller utpreget kapillaritt i alveolveggen.

Patologen bekreftet at de trombeliknende funn i kapillarene kunne skyldes kryoglobulinemi. Hemolytisk uremisk syndrom og trombotisk trombocytopenisk purpura kan gi liknende histologisk bilde med trombemasser i kapillarene. Denne diagnosen ble utelukket fordi det ikke var hemolyse eller trombocytopeni, og det var ingen schistocytter i blodutstryket. Sepsis ved for eksempel endokarditt kan gi liknende histologiske funn, men dette var ikke sannsynlig ut fra negative blodkulturer og normal ekkokardiografi.

Kryoglobulintest i serum var positiv. Mengden ble kvantitert til 0,26 g/l. Kryoglobulinet ble undersøkt med elektroforese og immunfiksasjon og besto av blanding av monoklonalt IgM-kappa og polyklonalt lgG, dvs. kryoglobulinemi type 2 (blandet). C3 var nå 0,59 $\mathrm{g} / \log \mathrm{C} 4<0,05 \mathrm{~g} / \mathrm{l}$.

Kryoglobuliner er immunglobuliner som presipiterer in vitro ved temperatur under kroppstemperatur. Type 2 kryoglobulinemi (før kalt essensiell) er en blandet type der presipitatet består av immunkomplekser av polyklonalt IgG samt monoklonalt IgM rettet mot IgG. Den monoklonale komponenten har altså revmatoid faktor- liknende aktivi-

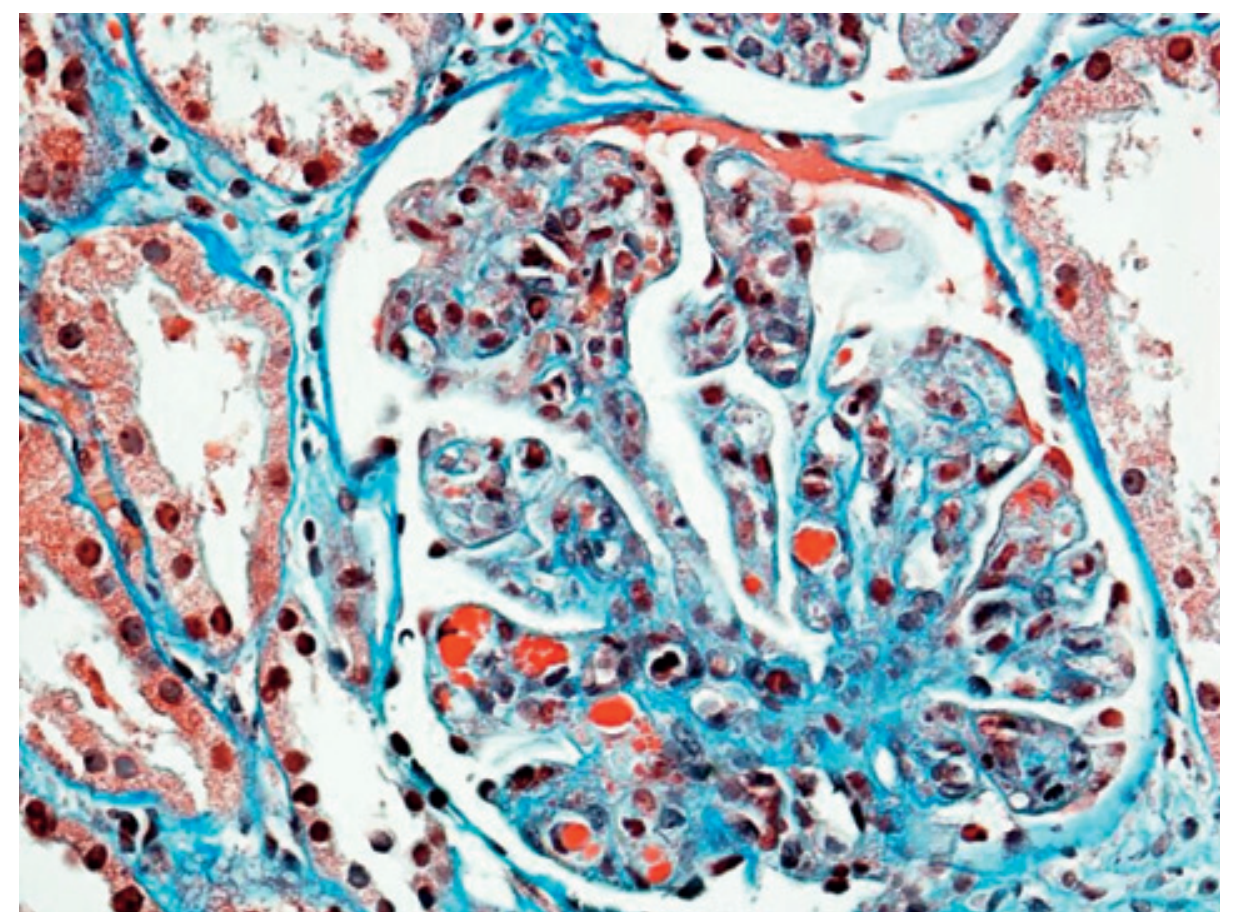

Figur 2 Nyrebiopsi med mikrotromber (rødt materiale) tet. Disse immunkompleksene aktiverer komplement som resulterer i vaskulitt. Studier har vist sterk assosiasjon til anti-HCVantistoffer i plasma og det er påvist HCVRNA i kryopresipitater (1).

Senere elektronmikroskopisk undersøkelse av nyrebiopsien kunne påvise mesangiokapillær (membranproliferativ) glomerulonefritt type 1, forenlig med utfelling av kryoglobuliner. Immunhistokjemisk etterundersøkelse viste nedslag av lgM og svakere kornet farging for lgG og C3 langs kapillarslyngene og i mesangiet i glomeruli. Sterk farging for IgM svarende til trombene i glomeruluskapillarer var forenlig med utfelling av kryoglobuliner. Hepatitt $C$-virus ble påvist med PCR i blodprøve tatt 19 d etter innkomst (fire døgn etter intuberingl og kvantitert til ca. $10 \cdot 10^{6}$ viruskopier $/ \mathrm{ml}$ blod.

Den livstruende tilstanden ble oppfattet som forårsaket av kryoglobulinemi. Det er funnet hepatitt C-antistoffer hos $41-53 \%$ av pasientene med blandet kryoglobulinemi (1). Kutan vaskulitt er den hyppigste plagen. Vår pasient hadde fått utslett på begge legger et halvt år tidligere etter å ha vasset over en fjellelv. Utslettet varte flere dager, var brunblått, indurert og ømt. Pasienten ble da testet for hepatitt C hos fastlegen. Dette utslettet samt de ømme kulene på anklene pasienten hadde ved innkomst, var trolig alt uttrykk for kutan vaskulitt.

Videre kan blandet kryoglobulinemi ved hepatitt $\mathrm{C}$ medføre nyreskade med det histologiske bilde membranproliferativ glomerulonefritt $(2,3)$. Sykdomsforløpet er oftest mildt. Det vanligste funnet er proteinuri, noen ganger i nefrotisk område. En sjelden gang gir blandet kryoglobulinemi dødelig sykdom med lungesymptomer og nyreaffeksjon (4). Det er tidligere beskrevet kasuistikker med utvikling av dyspné og respirasjonssvikt (5-8).

Behandling av alvorlig, livstruende kryoglobulinemi er fjerning av kryoglobuliner med plasmaferese og reduksjon av produksjon av kryoglobuliner med medikamentell immunsuppresjon (9). Start av slik behandling krever at man er sikker på at det ikke foreligger en aktiv infeksjon, da en kraftig immunsuppresjon ved pågående bakteriell sykdom ville kunne få fatale følger. Vi anså andre differensialdiagnoser ved renopulmonalt syndrom som mindre sannsynlige (10).

Det ble startet med Sendoxan 500 mg intravenøst og hun fikk Solumedrol 19 daglig i tre dager. I tillegg fikk hun fem plasmaferesebehandlinger i løpet av 12 dager, hver med utskifting av ett plasmavolum mot $4 \%$ albuminløsning. Den kliniske situasjonen bedret seg. Hun ble ekstubert ni døgn etter intubasjon og videre overflyttet til sengpost. Fire uker etter start av første plasmaferesebehandling fikk hun igjen purpura på leggene, og kryoglobulinmengden i serum var økt til $0,65 \mathrm{~g} / \mathrm{l}$. Hun ble derfor behandlet med ytterligere tre plasmafereser. 
Tabell 1 Årsaker til akutt oppstått kombinert nyre- og lungesykdom

\begin{tabular}{|lll}
\hline Vaskulitter & $\begin{array}{l}\text { Antistoffundersøkelse/andre } \\
\text { supplerende undersøkelser }\end{array}$ & $\begin{array}{l}\text { Viktigste biokjemiske } \\
\text { eller kliniske tegn }\end{array}$ \\
\hline \multicolumn{1}{|c|}{ Goodpastures syndrom } & - & - \\
\hline Wegeners granulomatose & Anti-GBM & - \\
\hline Systemisk lupus erythematosus & ANCA & - \\
\hline \multicolumn{1}{|c|}{ Sklerodermi } & Scl 70 & - \\
\hline \multicolumn{1}{|c|}{ Kryoglobulinemi } & Kryoglobuliner, lavt C4 & - \\
\hline $\begin{array}{l}\text { Hemolytisk uremisk syndrom/trom- } \\
\text { botisk trombocytopenisk purpura }\end{array}$ & $\begin{array}{l}\text { Schistocytter i Blodutstryk, } \\
\text { trombocytopeni }\end{array}$ & Hemolyse, utslett \\
\hline Antifosfolipidsyndrom & Cardiolipinantistoff & - \\
\hline $\begin{array}{l}\text { Medikamenter } \\
\text { Alvorlig lungeinfeksjon/sepsis med } \\
\text { glomerulonefritt eller akutt tubulær } \\
\text { nekrose }\end{array}$ & - & Anamnese \\
\hline Forgiftninger & Blodkulturer, ekkokardiografi & - \\
\hline
\end{tabular}

Hepatitt $\mathrm{C}$ er den hyppigste årsaken til blandet kryoglobulinemi. Vi mente derfor at det var riktig å iverksette behandling av hepatitt $\mathrm{C}$ med antivirale midler når den kliniske situasjonen hadde bedret seg $(11,12)$.

Etter påvisning av HCV-genotype 3, ble det startet behandling med ribavirin og pegylert interferon alfa-2a (Pagasys). HCV-RNA PCR var blitt negativ etter fire ukers behandling og har senere holdt seg negativ. 3 md etter igangsatt immunsuppressiv behandling var kryoglobulintest fortsatt svakt positiv, men mengden var bare $0,06 \mathrm{~g} / \mathrm{l}$.

\section{Videre forløp}

Atte måneder etter første innleggelse, fikk hun igjen dyspné, febertopper med temperatur over $40^{\circ} \mathrm{C}$, magesmerter og nefrotisk
proteinuri.Hun hadde da vært to uker uten antiviral behandling. Sigmoidoskopi viste inflammatoriske forandringer i rectum, Biopsi fra området kunne være forenlig med iskemiske forandringer. S-kryoglobulin hadde steget til 0,4 g/l. Initialt ble hun behandlet for antatt infeksjon med ciprofloksacin og penicillin. Tilstanden ble etter hvert oppfattet som oppblussing av kryoglobulinemi, og hun ble behandlet med Solumedrol $500 \mathrm{mg}$ daglig i tre dager, fortsatte med Prednisolon $0,5 \mathrm{mg} / \mathrm{kg}$ med langsom nedtrapping til 0,2 $\mathrm{mg} / \mathrm{kg} / \mathrm{dag}$ over $5 \mathrm{md}$. og seponering etter 9 md. På bakgrunn av nyere anbefalinger for behandling av blandet kryoglobulinemi fikk hun Rituximab 375 $\mathrm{mg} / \mathrm{m}^{2}$, $i$ alt fire intravenøse infusjoner à 550 mg med en ukes mellomrom (13). 22 måneder etter første gangs innleggelse var hun $i$

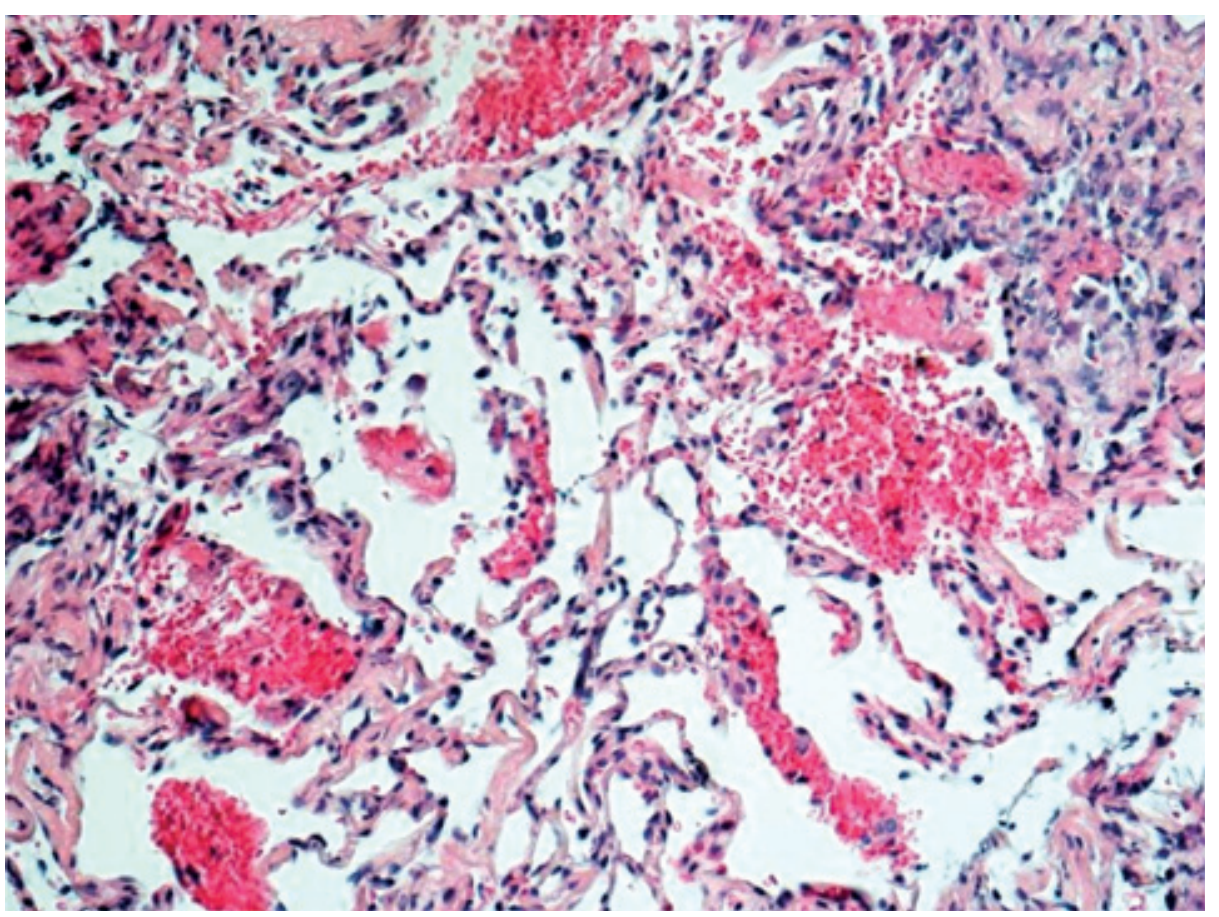

god allmenntilstand, hun hadde gått litt på ski og klarte daglige gjøremål. Hun hadde ikke kuldeintoleranse. Blodprøvene viste kreatinin $80 \mu \mathrm{mol} / \mathrm{l}, \mathrm{CRP} 3 \mathrm{mg} / \mathrm{l}, \mathrm{Hb} 12 \mathrm{~g} /$ $100 \mathrm{ml}$, leukocytter $10,4 \cdot 10^{9} /$, trombocytter $231 \cdot 10^{9} / \mathrm{l}$, C3 1,54 g/l, C4 0,11 g/log kryoglobulintest negativ.

\section{Diskusjon}

Vår pasient hadde transaminasestigning, lav albuminverdi og påvist hepatitt $\mathrm{C}$-antistoffer ved innkomst. Ved en grundig og gjentatt anamnese, kunne vi kommet frem til diagnosen tidligere. Ved innleggelse hadde pasienten to ukers sykehistorie med feber, og etter en uke med fortsatt feber på sykehuset oppfylte hun kriteriene for diagnosen feber av ukjent årsak. Utredning av feber burde nok startet tidligere og ikke etter ti døgn med antibiotikabehandling.

Pasienten utviklet respirasjonssvikt som klinisk og histologisk er forenlig med hemoragisk alveolitt. Dette er en sjelden, men alvorlig komplikasjon til kombinert essensiell kryoglobulinemi. I publiserte kasuistikker, er det beskrevet effekt på denne lungekomplikasjonen ved bruk av syklofosfamid og plasmaferese (8-11). Dersom pasienten hadde fått denne behandlingen tidligere $\mathrm{i}$ forløpet, er det en mulighet for at hun ikke hadde utviklet lungesvikt.

En moderat økning av s-kreatininnivået hos intensivpasienter tillegges ofte liten vekt. Dette gjelder spesielt ved sykdomstilstander der symptomer fra et annet organ enn nyre er dominerende. Hos denne pasienten var urinfunn og moderat økt s-kreatininnivå medvirkende til at man utførte nyrebiopsi og derved stilte riktig diagnose. Gjentatte urinundersøkelser kan være av avgjørende betydning for diagnostisering av nyresykdom under et langvarig uklart sykdomsforløp.

Urinsedimentundersøkelse med mikroskopi utføres vanligvis av turnuskandidater i norske sykehus. Etter vår erfaring er denne prosedyren ikke kvalitetssikret. Turnuskandidaters kunnskap om urinmikroskopi er ofte utilstrekkelig. Den legen som er ansvarlig for pasienten, bør gjøre urimmikroskopi, eventuelt i samarbeid med nefrolog. Dette krever nødvendig opplæring under studiet og i spesialistutdanningen - og også praktisk tilrettelegging $i$ en klinisk hverdag. Indikasjon for nyrebiopsi er mistenkt parenkymatøs nyresykdom hvor biopsifunnet har behandlingsmessig betydning.

Pasienten har gitt samtykke til at artikkelen blir publisert.

Figur 3 Lungebiopsi med utbredt blødning, men ikke påvist kapillaritt 
Ingrid Lyngved Ødegård

ingrid.lyngved.odegard@sykehuset-innlandet.no Anestesiavdelingen

Sykehuset Innlandet Lillehammer

2609 Lillehammer

\section{Kolbjørn Høgåsen}

\section{Dag Paulsen}

Nyreseksjonen

Medisinsk avdeling

Sykehuset Innlandet Lillehammer

\section{Helge Scott}

Patologisk avdeling

Oslo universitetssykehus, Rikshospitalet

\section{Oppgitte interessekonflikter: Ingen}

\section{Litteratur}

1. Cacoub P, Fabiani FL, Musset L. Mixed cryglobulinemia and hepatitis $C$ virus. Am J Med 1994: 96 : 124-32

2. Kamar N, Rostaing $L$, Alric L. Treatment of hepatitis C-virus-related glomerulonephritt. Kidney Int 2006; 69: 436-9.
3. Campise M, Tarantino A. Glomerulonephritis in mixed cryoglobulinaemia: what treatment. Nephrol Dial Transplant 1999; 14: $281-3$.

4. Mazzaro C, Pozzato G, Zorat F et al. Etiologic treatment of hepatitis $C$ virus-associated mixed cryoglobulinemia. Dig Liver Dis 2007; 39 (suppl 1): $102-8$

5. Johnson RJ, Gretch DR, Yamabe $\mathrm{H}$ et al. Membranoproliferativ glomerulonephritis associated with hepatitis C virus infection. N Engl J Med 1993: 18 . 465-70.

6. Roccatello D, Fornasieri A, Giachino 0 et al. Multicenter study on hepatitis $C$ virus-related cryoglobulinemic glomerulonephritis. Am J Kidney Dis 2007: 49: 69-82

7. Roithinger FX, Allinger S, Kirchgatterer A et al A Lethal course of chronic hepatitis C, glomerulonephritis and pulmonary vaskulitis unresponsive to interferon treatment. Am J Gastroenterol 1995; 90: $1006-8$

8. Gomez-Tello V, Onoro-Canaveral JJ, de la Casa Monje RM et al. Diffuse recidivant alveolar hemorrhage in a patient with hepatitis $\mathrm{C}$ virus-related mixed cryoglobulinemia. Intensive Care Med 1999. 25: $319-22$.

9. Suzuki R, Morita H, Komukai D et al. Mixed cryoglobulinemi due to chronic hepatitis $\mathrm{C}$ with severe pulmonary involvement. Intern Med 2003. 12: $1210-4$

10. Chejfec G, Lichtenberg L, Lertratanakul Y. Respiratory insufficiency in a patient with mixed cryoglobulinemi. Ultrastruct Pathol 1981; 2: 295-302.

11. Stagg M, Lauber J, Michalski MD. Mixed essential cryoglobulinemia and adult respiratory distress syndrome: a case report. Am J Med 1989; 87: 445-8

12. Garini G, Allegri L, lannuzzella F et al. HCV-related cryoglobulinemic glomerulonephritis: implications of antiviral and immunosuppressive therapies. Acta Biomed 2007; 78: 51-9

13. Jara LJ, Vera-Lastra O, Calleja MC. Pulmonaryrenal vasculitic disorders: differential diagnosis and management. Curr Rheumatol Rep 2003; 5 $107-15$.

Manuskriptet ble mottatt 29.1. 2009 og godkjent 30.7. 2009. Medisinsk redaktør Anne Kveim Lie.

\section{Når det åpenbare ikke er det vanlige}

Det er anslått at opptil 30000 personer kan være infisert med Hepatitt $\mathrm{C}$ i Norge (1). Viruset er kjent for sine hepatotrope egenskaper med fare for utvikling av kronisk hepatitt, levercirrhose og hepatocellulært karsinom, men det er mindre kjent at viruset kan medfører en del ekstrahepatiske manifestasjoner (2). De fleste av disse er autoimmune sykdommer, som tenkes utløst enten av stimulering av autoreaktive B-celler ved vedvarende virale proteiner eller via en direkte lymfotrop effekt av selve viruset. Kryoglobuliner er det hyppigste biologiske funn og påvises hos $50-60 \%$, mens antinukleære antistoffer $(40 \%)$, revmatoid faktor $(29 \%)$ og antiglatt muskulatur-antistoffer $(10 \%)$ også er frekvente funn (3). Til tross for dette utvikler bare en mindre del av pasienter manifest ekstrahepatisk sykdom som artralgier, siccasyndrom, nevropati, vaskulitt, tyreoiditt og lymfom (3). Kryoglobuliner er immunglobuliner (Ig) som kjennetegnes ved at de ikke lenger er løselige ved temperaturer lavere enn kroppstemperatur, og at de kan løses opp igjen ved oppvarming av serum (4). Påvisning av kryoglobuliner er krevende siden ukorrekt prøvehåndtering (f.eks. nedkjøling ved lang transport) kan ødelegge proteiner. Om kryoglobulinemi vil føre til nedslag av kryoglobuliner i kroppen og utløse en inflammasjonstilstand, er avhengig av mengden av kryoglobuliner og sammensetningen. Analyse ved hjelp av immunofiksasjon kan vise om de består av et monoklonalt Ig (definert som type I kryoglobulinemi; oftest sett ved plasmacelledyskrasier) eller en kombinasjon av et monoklonalt (spesielt av IgM type) og polyklo- nalt Ig (definert som type II eller blandet kryoglobulinemi (4).

I den beskrevne kasuistikken utviklet pasienten en vaskulittilstand assosiert med blandet kryoglobulinemi, noen måneder etter at hun fikk påvist hepatitt C-antistoffer. Kryoglobulinassosiert småkarsvaskulitt forekommer som selvstendig autoimmun sykdom, men er oftest (60-80\%) relatert til hepatitt $\mathrm{C}$-infeksjon. Likevel utvikler ikke mer enn $2-4 \%$ av pasienter med hepatitt $C$ (3) slik småkarsvaskulitt, og det er sjelden at forløpet blir så alvorlig. Kasuistikken er dermed interessant i seg selv, men byr ellers på flere læringsmomenter.

Pasienten hadde nydebuterte små, ømme hevelser på leggene, som mest sannsynlig representerte enten erythema nodosum (fettvevsnekrose) eller purpura allerede ved innleggelse. Det er uklart om og hvordan disse lesjoner ble tolket, men at viktige funn i huden på uforklarlig vis blir oversett, er en kjent diagnostisk fallgruve ved inflammatoriske systemsykdommer. Pasienten hadde ellers nedsatt nyrefunksjon, uttalt hypalbuminemi med fortsatt moderat proteinuri samt hematuri. Nærmere en klinisk beskrivelse av glomerulonefritt kommer man neppe. At det endelige beviset for glomerulær affeksjon ved funn av cellesylindre kom først etter at urinmikroskopering ble gjentatt av mer erfaren fagfolk, viser hvor viktig opplæring og erfaring med urinmikroskopering er.

Pasienten ble behandlet med et tredjegenerasjons kefalosporinpreparat, selv om det ikke forelå åpenbare kliniske tegn til pneumoni, urinveisinfeksjon eller sepsis.
Dette passer dårlig med anbefalinger om fornuftig bruk av antibiotika i sykehus (5) og bidro til at de åpenbare tegnene på den bakenforliggende systemisk inflammatoriske sykdommen lenge ble oversett. Når det åpenbare ikke stemmer med det vanlige, er det - også $i$ travle hverdager indisert med en kort tenkepause. Dette kunne ha spart pasienten for en Clostridium difficile-infeksjon, og etter all sannsynlighet også for utvikling av hemoragisk alveolitt under sykehusoppholdet.

\section{Johannes Cornelis Nossent}

hans.nossent@unn.no

Revmatologisk avdeling

Universitetssykehuset Nord-Norge

9038 Tromsø

\section{Oppgitte interessekonflikter: Ingen}

\section{Litteratur}

1. Vik IS, Skaug K, Dalgard O et al. Hepatitt C et helseproblem også i Norge. Tidsskr Nor Legeforen 2008; 128: 563-6.

2. Kristiansen MG. Florholmen J. Ekstrahepatiske manifestasjoner ved hepatitt C-infeksjon. Blir de oversett? Tidsskr Nor Lægeforen 2001; 121 $446-9$

3. Cacoub P Renou C. Rosenthal E et al. Extrahepatic manifestations associated with hepatitis $C$ virus infection. A prospective multicenter study of 321 patients. The GERMIVIC. Groupe d'Etude et de Recherche en Medecine Interne et Maladies Infectieuses sur le Virus de l'Hepatite C. Medicine (Baltimore) 2000; 79: 47-56.

4. Ferri C, Mascia MT. Cryoglobulinemic vasculitis Curr Opin Rheumatol 2006; 18: 54-63.

5. Berild D, Haug JB. Fornuftig bruk av antibiotika i sykehus. Tidsskr Nor Legeforen 2008; 128: 2335-9. 